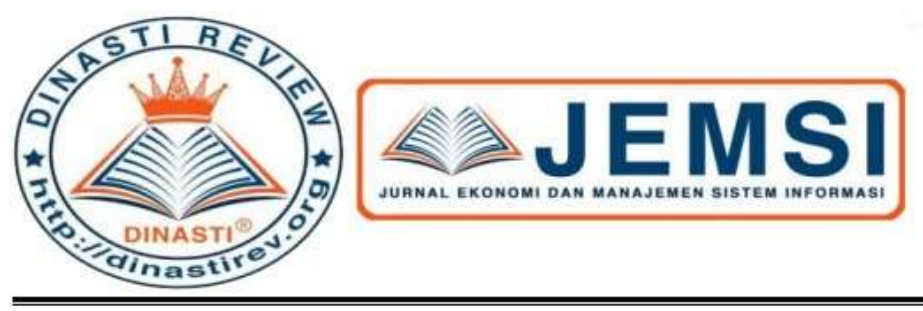

$+62878-9658-6407$ (c)

087896586407 (Q)

https://dinastirev.org/JEMSI (7)

editor@dinastirev.org@.

\title{
PEDOMAN PERILAKU DALAM ETIKA BISNIS DI PT. KF
}

\author{
Happy Nur Fitri Handayani \\ Universitas Mercu Buana, Jakarta, Indonesia
}

\begin{tabular}{|c|c|}
\hline $\begin{array}{c}\text { ARTICLE INFORMATION } \\
\text { Received: } 24 \text { November } 2019 \\
\text { Revised: } 26 \text { November } 2019 \\
\text { Issued: } 30 \text { November } 2019 \\
\text { (filled in by Editor) } \\
\text { Corresponding author: first author } \\
\text { E-mail: } \\
\text { happyNFH@gmail.com }\end{array}$ & $\begin{array}{l}\text { Abstrak: Dalam sebuah perusahaan peranan etika } \\
\text { bisnis dalam pengaturan dan pengelolaan bisnis yang } \\
\text { memperhatikan norma dan moralitas yang berlaku } \\
\text { secara universal secara ekonomi maupun social dan } \\
\text { memiliki keterkaitan dengan profesional bisnis. } \\
\text { Penulisan artikel ini bertujuan untuk mengetahui } \\
\text { bagaimanakah peranan etika bisnis di PT. KF. Hasil } \\
\text { Penelitian ini menunjukkan bahwa PT. KF } \\
\text { menjalankan peranan Etika Bisnis sebagai pedoman } \\
\text { berperilaku bagi seluruh jajaran PT. KF dalam } \\
\text { melakukan interaksi dan hubungan dengan segenap } \\
\text { pemangku kepentingan. } \\
\text { Kata Kunci: Etika Bisnis, Pedoman Perilaku }\end{array}$ \\
\hline
\end{tabular}

\section{PENDAHULUAN}

Perusahaan yang menggunakan peranan Etika Bisnis dapat membentuk nilai, norma dan perilaku pimpinan dalam membangun hubungan yang adil, sehat dengan mitra kerja, pelanggan, pemegang saham, karyawan dan masyarakat sekitar. Etika bisnis adalah suatu pengetahuan tentang tata cara ideal pengaturan dan pengelolaan bisnis yang memperhatikan norma dan moralitas yang berlaku secara universal (Muslich, 2004:9).

Arti etika dapat dibedakan dari sisi praktis dan refleksi. Etika sebagai praktis yaitu sejauhmana nilai-nilai dan norma-norma moral diterapkan dan dilaksanakan dalam berbagai aktivitas dan kegiatan sehari hari, sedangkan Etika sebagai refleksi adalah pemikiran moral, dimana kita berfikir tentang apa yang dilakukan lebih spesifik yang harus dilakukan atau tidak boleh dilakukan. Etika sebagai refleksi menyoroti dan menilai baik buruknya perilaku orang.

Etika berfungsi menggugah kesadaran moral pelaku bisnis untuk berbisnis secara baik dan etis didasari nilai-nilai luhur yang bermanfaat bagi konsumen, masyarakat dan demi menjaga nama baik bisnis sendiri dalam jangka panjang. Etika bisnis menjadi acuan bagi pebisnis untuk berbisnis tanpa merugikan konsumen, buruh, karyawan, dan masyarakat luas. 
Berdiri pada tahun 1966, PT. KF telah jauh berkembang dari usaha sederhana di sebuah garasi menjadi perusahaan farmasi terdepan di Indonesia. Melalui proses pertumbuhan organik dan penggabungan usaha \& akuisisi, PT. KF telah tumbuh dan bertransformasi menjadi penyedia solusi kesehatan terintegrasi melalui 4 kelompok divisi usahanya: Divisi Obat Resep (kontribusi 23\%), Divisi Produk Kesehatan (kontribusi 17\%), Divisi Nutrisi (kontribusi 30\%), serta Divisi Distribusi and Logistik (kontribusi 30\%).

Keempat divisi usaha ini mengelola portofolio obat resep dan obat bebas yang komprehensif, produk-produk minuman energi dan nutrisi, serta usaha distribusi yang menjangkau lebih dari satu juta outlet di seluruh kepulauan Indonesia.

Etika Bisnis pada PT KF merupakan pedoman berperilaku bagi seluruh jajaran PT. KF (termasuk Dewan Komisaris dan Direksi Perseroan) dalam melakukan interaksi dan hubungan dengan segenap pemangku kepentingan. Kode Etik tersebut dikembangkan dengan mengacu pada prinsip-prinsip tata kelola perusahaan yang baik dan merupakan nilainilai perusahaan yang menjiwai perkembangan sejarah PT. KF.

\section{KAJIAN PUSTAKA}

\section{Etika Bisnis}

Menurut Muslich (2004 : 9) Etika bisnis adalah suatu pengetahuan tentang tata cara ideal pengaturan dan pengelolaan bisnis yang memperhatikan norma dan moralitas yang berlaku secara universal. Etika bisnis merupakan aturan tidak tertulis mengenai cara menjalankan bisnis secara adil, sesuai dengan hukum yang berlaku dan tidak tergantung pada kedudukan individu atau-pun perusahaan di masyarakat.

Menurut Bertens (2000) Etika bisnis lebih luas dari ketentuan yang diatur oleh hukum, bahkan merupakan standar yang lebih tinggi dibandingkan standar minimal ketentuan hukum, karena dalam kegiatan bisnis seringkali kita temukan wilayah abu-abu yang tidak diatur oleh ketentuan hukum.

Menurut Bertens (2000: 32) Etika sebagai praktis yaitu sejauhmana nilai-nilai dan norma-norma moral diterapkan dan dilaksanakan dalam berbagai aktivitas dan kegiatan sehari hari. Atau dapat juga di artikan sebagai apa yang dilakukan sesuai dengan nilai dan moral. Etika sebagai praktis berarti moral atau moralitas: apa yang harus dilakukan, tidak boleh dilakukan, pantas dilakukan dan sebagainya. Etika sebagai refleksi adalah pemikiran moral, dimana kita berfikir tentang apa yang dilakukan lebih spesifik yang harus dilakukan atau tidak boleh dilakukan. Etika sebagai refleksi menyoroti dan menilai baik buruknya perilaku orang.

Menurut Pandji (2007:113) etika bisnis adalah Etika (Ethics) yang menyangkut tata pergaulan di dalam kegiatan-kegiatan bisnis. Bisnis adalah kegiatan-kegiatan teratur yang melayani kebutuhan yang bersifat umum (artinya: non-personal) sambil memeperoleh pendapatan (Income). Jika di dalam "pendapatan" itu dikalkulasikan laba, maka bisnis tersebut bersifat komersial.

\section{Aspek Dan Sudut Pandang Etika Bisnis}

Menurut Bertens (2000) terdapat tiga aspek dan sudut pandang pokok dari bisnis, yaitu:

1. Sudut pandang ekonomi, bisnis adalah kegiatan ekonomis, maksudnya adalah adanya interaksi produsen/perusahaan dengan pekerja, produsen dengan produsen dalam sebuah organisasi. Kegiatan antar manusia ini adalah bertujuan untuk mencari untung 
oleh karena itu menjadi kegiatan ekonomis. Pencarian keuntungan dalam bisnis tidak bersifat sepihak, tetapi dilakukan melalui interaksi yang melibatkan berbagai pihak.

2. Sudut pandang etika, dalam bisnis berorientasi pada profit adalah sangat wajar, akan tetapi jangan keuntungan yang diperoleh tersebut justru merugikan pihak lain. Maksudnya adalah, semua yang kita lakukan harus menghormati kepentingan dan hak orang lain.

3. Sudut pandang hukum, bisa dipastikan bahwa kegiatan bisnis juga terikat dengan Hukum Dagang atau Hukum Bisnis, yang merupakan cabang penting dari ilmu hukum modern. Dalam praktik hukum banyak masalah timbul dalam hubungan bisnis pada taraf nasional maupun internasional. Seperti etika, hukum juga merupakan sudut pandang normatif, karena menetapkan apa yang harus dilakukan atau tidak boleh dilakukan.

\section{Prinsip - Prinsip Etika Bisnis}

Etika bisnis memiliki prinsip-prinsip yang bertujuan memberikan acuan cara yang harus ditempuh oleh perusahaan untuk mencapai tujuannya.

Menurut Sonny Keraf (1998) terdapat lima prinsip yang dijadikan titik tolak pedoman perilaku dalam menjalankan praktik bisnis, yaitu :

1. Prinsip Otonomi, Prinsip otonomi menunjukkan sikap kemandirian, kebebasan, dan tanggung jawab. Orang yang mandiri berarti orang yang dapat mengambil suatu keputusan dan melaksanakan tindakan berdasarkan kemampuan sendiri sesuai dengan apa yang diyakininya, bebas dari tekanan, hasutan, dan ketergantungan kepada pihak lain.

2. Prinsip Kejujuran, Prinsip kejujuran menanamkan sikap bahwa apa yang dipikirkan adalah apa yang dikatakan, dan apa yang dikatakan adalah yang dikerjakan. Prinsip ini juga menyiratkan kepatuhan dalam melaksanakan berbagai komitmen, kontrak, dan perjanjian yang telah disepakati.

3. Prinsip Keadilan, Prinsip keadilan menanamkan sikap untuk memperlakukan semua pihak secara adil, yaitu suatu sikap yang tidak membeda-bedakan dari berbagai aspek baik dari aspek ekonomi, hukum, maupun aspek lainnya.

4. Prinsip saling Menguntungkan, Prinsip saling menguntungkan menanamkan kesadaran bahwa dalam berbisnis perlu ditanamkan prinsip win-win solution, artinya dalam setiap keputusan dan tindakan bisnis harus diusahakan agar semua pihak merasa diuntungkan.

5. Prinsip Integritas Moral, Prinsip integritas moral adalah prinsip untuk tidak merugikan orang lain dalam segala keputusan dan tindakan bisnis yang diambil. Prinsip ini dilandasi oleh kesadaran bahwa setiap orang harus dihormati harkat dan martabatnya.

Menurut pendapat Michael Josephson dalam Pandji (2007:125), secara universal ada 10 prinsip etika yang mengarahkan perilaku, yaitu :

1. Kejujuran, yaitu penuh kepercayaan, tidak curang, dan tidak berbohong.

2. Integritas, yaitu memegang prinsip, melakukan kegiatan terhormat, tulus hati, berani dan penuh pendirian, tidak bermuka dua, tidak berbuat jahat dan saling percaya.

3. Memelihara janji, yaitu selalu menaati janji, patut dipercaya, penuh komitmen, patuh.

4. Kesetiaan, yaitu hormat dan loyal kepada keluarga, teman, karyawan, dan negara; jangan menggunakan atau memperlihatkan informasi yang diperoleh dalam kerahasiaan; begitu juga dalam suatu konteks professional, jaga/lindungi kemampuan untuk membuat keputusan professional yang bebas dan teliti, hindari hal yang tidak pantas dan konflik kepentingan. 
5. Kewajaran/Keadilan, yaitu berlaku adil dan berbudi luhur, bersedia untuk mengakui kesalahan; dan memperlihatkan komitmen keadilan, persamaan perlakuan individual dan toleran terhadap perbedaan, jangan bertindak melampaui batas atau mengambil keuntungan yang tidak pantas dari kesalahan atau kemalangan orang lain.

6. Suka membantu orang lain, yaitu saling membantu, barbaik hati, belas kasihan, tolong menolong, kebersamaan, dan menghindari segala sesuatu yang membahayakan orang lain.

7. Hormat kepada orang lain, yaitu menghormati martabat manusia, menghormati kebebasan dan hak untuk menentukan nasib sendiri bagi semua orang, bersopan santun, jangan merendahkan diri seseorang, jangan memperlakukan seseorang dan jangan merendahkan martabat orang lain.

8. Kewarganegaraan yang bertanggung jawab, yaitu selalu mentaati hukum/aturan, penuh kesadaran sosial, menghormati proses demokrasi dalam mengambil keputusan.

9. Mengejar keunggulan, yaitu mengejar keunggulan dalam hal baik dalam pertemuan personal maupun pertanggungjawaban professional, tekun, dapat dipercaya/diandalkan, rajin dan penuh komitmen, melakukan semua tugas dengan yang terbaik berdasar kemampuan, mengmbangkan, dan memperhahankan tingkat kompetensi yang tinggi.

10. Dapat dipertanggung jawabkan, yaitu memilki tanggung jawab, meneri,a tanggung jawab atas keputusan dan konsekuensinya, dan selalu mencari contoh.

\section{Peranan Etika Bisnis}

Etika berfungsi menggugah kesadaran moral pelaku bisnis untuk berbisnis secara baik dan etis didasari nilai-nilai luhur yang bermanfaat bagi konsumen, masyarakat dan demi menjaga nama baik bisnis sendiri dalam jangka panjang. Etika bisnis menjadi acuan bagi pebisnis untuk berbisnis tanpa merugikan konsumen, buruh, karyawan, dan masyarakat luas.

Dalam modul Hapzi Ali (2019) alasan bisnis berlaku etis ada tiga dasar yang mendasarinya yaitu ajaran agama (tuhan yang maha kuasa), kepentingan sosial dan perilaku pebisnis yang bernilai utama :

1. Ajaran Agama (Tuhan Yang Maha Esa)

Agama mengatakan bahwa sesudah kehidupan jasmani ini manusia akan hidup terus dalam dunia baka, di mana Tuhan sebagai Hakim Maha Agung akan menghukum kejahatan yang pernah dilakukan dan mengganjar kebaikannya.

2. Kontrak Sosial

Segala sesuatu yang dilakukan oleh seorang pebisnis akan selalu berhubungan dengan tingkat kesejahteraan masyarakat, maka pebisnis dalam interaksi bisnisnya memiliki kontrak sosial dengan masyarakat tempat dimana ia berbisnis untuk selalu menciptakan kesejahteraan dalam kegiatan bisnisnya.

3. Keutamaan

Keutamaan sebagai ukuran untuk melakukan bisnis terbaik, merupakan penyempurnaan tertinggi kodrat manusia.

\section{METODE PENELITIAN}

Data yang digunakan adalah data sekunder, yaitu data yang diperoleh penulis secara tidak langsung atau melalui media perantara dari website, jurnal - jurnal peneliian terdahulu. Metode pengumpulan data dalam penelitian ini menggunakan studi kepustakaan yaitu dengan 
menelaah terhadap buku - buku, literature - literature, catatan - catatan dan laporan laporan yang ada hubungannya dengan penelitian yang diteliti.

\section{HASIL DAN PEMBAHASAN}

Etika Bisnis PT. KF merupakan pedoman berperilaku bagi seluruh jajaran PT. KF (termasuk Dewan Komisaris dan Direksi Perseroan) dalam melakukan interaksi dan hubungan dengan segenap pemangku kepentingan. Kode Etik tersebut dikembangkan dengan mengacu pada prinsipprinsip tata kelola perusahaan yang baik dan kepada Panca Sradha Kalbe yang merupakan nilainilai perusahaan yang menjiwai perkembangan sejarah PT. KF.

Panca Sradha Kalbe

1. Saling percaya adalah perekat di antara kami.

2. Kesadaran penuh adalah dasar setiap tindakan kami.

3. Inovasi adalah kunci keberhasilan kami.

4. Bertekad untuk menjadi yang terbaik.

5. Saling keterkaitan adalah panduan hidup kami.

Kelima aspek ini menjadi dasar bagi setiap insan Kalbe dalam bersikap, berperilaku dan berinteraksi dengan para stakeholders Kalbe. Etika Bisnis Kalbe dapat menghindari terjadinya penyimpangan terhadap standar perilaku yang ditetapkan dan menjadi pedoman dalam mendeteksi pelanggaran yang terjadi.

Kepatuhan terhadap Etika Bisnis Kalbe akan menghindari timbulnya hubungan yang tidak wajar dengan para pemangku kepentingan yang pada kelanjutannya akan merugikan Perseroan. Pokok-pokok Etika Bisnis Kalbe mencakup standar perilaku dan kepatuhan terhadap hukum dan perundang-undangan, komitmen terhadap karyawan, pemegang saham, mitra usaha, prinsipprinsip persaingan usaha, integritas bisnis, benturan kepentingan, standar produk dan layanan, penghargaan atas hak kekayaan intelektual, komitmen terhadap lingkungan, kemitraan dengan masyarakat, serta aktivitas organisasi dan politik.

Penyusunan Etika Bisnis Kalbe bertujuan untuk mencapai tujuan-tujuan berikut:

1. Menjabarkan nilai-nilai Perusahaan ke dalam standar etika bisnis yang harus dipatuhi oleh setiap insan Kalbe dalam pelaksanaan tugas sehari-hari.

2. Menjadi standar pedoman perilaku yang diharapkan atas setiap insan Kalbe, meliputi Komisaris, Direksi dan karyawan.

3. Mengembangkan perilaku yang baik sesuai dengan standar etika yang tinggi bagi korporasi, Komisaris, Direksi dan seluruh karyawan.

4. Mengembangkan hubungan yang baik dengan para pemangku kepentingan sesuai dengan prinsip-prinsip tata kelola dan nilai-nilai Perusahaan.

5. Menunjang pelaksanaan praktek tata kelola yang baik dalam Perusahaan dalam rangka mencapai kinerja keuangan, sosial dan lingkungan yang baik dan berkelanjutan.

Peluncuran Etika Bisnis diikuti dengan program sosialisasi bertahap yang akan menjangkau seluruh insan Kalbe. Sosialisasi dilakukan secara berjenjang untuk memastikan bahwa seluruh lapisan karyawan memiliki pemahaman yang sama atas prinsip Etika Bisnis Kalbe. Selain kewajiban untuk mentaati Etika Bisnis Kalbe, karyawan Kalbe juga akan diwajibkan mematuhi aturan dan kebijakan Perseroan lainnya serta tidak bersikap diam apabila menemukan atau mengetahui perbuatan atau tindakan yang merupakan pelanggaran 
atas Etika Bisnis Kalbe. Karyawan wajib melaporkan pelanggaran atas Etika Bisnis Kalbe tersebut melalui Whistleblowing System.

Pedoman Etika Kalbe yang sedang dikembangkan berisikan aspek-aspek antara lain kepatuhan terhadap hukum dan peraturan, penghindaran benturan kepentingan, pemberian dan penerimaan hadiah / gratifikasi, keterlibatan dalam kegiatan politik dan lain-lain.

Komite Audit PT. KF mempunyai kode etik sebagai berikut:

1. Menjunjung tinggi integritas, profesionalisme dan standar profesi dalam melaksanakan tugas sebagai Komite Audit;

2. Melaksanakan setiap tugas dan tanggungjawab secara jujur, obyektif dan independen semata-mata untuk kepentingan Perseroan;

3. Menghindari kegiatan yang bertentangan dengan hukum, etika dan norma-norma yang berlaku di masyarakat serta kegiatan yang bertentangan dengan kepentingan dan tujuan Perseroan;

4. Tidak menerima imbalan atau sesuatu apapun diluar dari yang sudah ditetapkan sebagai penghargaan atas tugasnya;

5. Memberikan pendapat dengan menggunakan bukti yang cukup dan kompeten untuk mendukung pendapat tersebut serta tidak menggunakan informasi yang berkaitan dengan Perseroan untuk keuntungan pribadi;

6. Menjaga kerahasiaan informasi Perseroan dan tidak akan mengungkapkan informasi tersebut kecuali dibenarkan oleh peraturan perundang-undangan yang berlaku.

7. Mengembangkan kemampuan dan keahlian profesional secara berkelanjutan.

\section{KESIMPULAN DAN SARAN}

\section{Kesimpulan}

Adanya Etika bisnis merupakan suatu pedoman yang sangat penting dalam kegiatan bisnis. Pelaku bisnis harus mampu memahami dan mengintrepretasikan apa yang dimaksud dengan etika bisnis. Etika bisnis menjadi sangat penting bagi kelangsungan hidup suatu perusahaan, maksudnya adalah keberlangsungan hidup suatu perusahaan bergantung pada bagaimana cara penerapan etika bisnis oleh pelaku bisnis.

Dengan terapkannya etika dalam bisnis, maka secara tidak langsung dapat menumbuhkan kepercayaan dari rekan kerja, masyarakat, dan pelanggan, di mana kepercayaan merupakan sebuah modal yang sangat penting agar kelangsungan hidup perusahaan tetap terjamin. Maka dari itu, perusahaan memiliki tanggung jawab untuk mempertahankan atau bahkan meningkatkan standar etika.

Pedoman Etika yang dimiliki oleh PT. KF berdasar pada prinsip-prinsip tata kelola perusahaan yang baik dengan adanya Panca Sradha Kalbe yaitu: saling percaya adalah perekat di antara kami, kesadaran penuh adalah dasar setiap tindakan kami, inovasi adalah kunci keberhasilan kami, bertekad untuk menjadi yang terbaik dan saling keterkaitan adalah panduan hidup kami. Kelima aspek ini menjadi dasar bagi setiap insan Kalbe dalam bersikap, berperilaku dan berinteraksi dengan para stakeholders PT. KF.

\section{Saran}

1. Untuk PT. KF agar tetap berpegang teguh pada prinsip - prinsip Etika Bisnis dalam Panca Sradha Kalbe yang memiliki lima aspek sebagai dasar bagi pedoman Etika Bisnis.

2. Untuk pembaca agar dapat meneliti artikel ini lebih dalam lagi karena pasti ada pembaharuan dari Etika Bisnis di PT. KF 


\section{DAFTAR RUJUKAN}

Ali, Hapzi . 2019. Modul Perkuliahan Etika Bisnis dan Good Governance Univesitas Mercubuana. Principles of Personal Ethics dan Principles of Professional Ethics. Universitas Mercu Buana.

Anogara, Pandji. 2007. Pengantar Bisnis Pengelolaan Bisnis Dalam Era Globalisasi. Jakarta: Rineka

Bertens K. 2000. Pengantar Etika Bisnis, Edisi Keenam. Yogyakarta: Kanisius.

https://www.kajianpustaka.com/2016/10/pengertian-prinsip-dan-manfaat-etika-bisnis.html https://www.kalbe.co.id/id/tata-kelola-perusahaan/etika

Keraf, A. Sonny. 1998. Etika Bisnis. Jakarta : Penerbit Kanisius

Muslich, Mohammad. 2004. Manajemen Keuangan Modern, Analisis Perencanaan dan Kebijakan. Cetakan Pertama. Jakarta: Bumi Aksara. 